\title{
Women's expatriate careers: losing trust in organisational equality and diversity policy implementation?
}

\begin{abstract}
Design/methodology/approach

A cross-sectional, qualitative research approach draws upon in-depth semi-structured interviews with 14 Human Resources equality/diversity policy implementers and 26 current female expatriates in two oil and gas firms.
\end{abstract}

Purpose

This purpose of this paper is to examine how female expatriates interpret the effectiveness of practical implementation of equality/diversity policies, trusting this to support their expatriate careers.

\section{Findings}

Early-career stage female expatriates believe that equality/diversity policy implementation will support their international careers. At the most senior levels, women expatriates highlight unequal treatment breaching their trust in delivery of equality/diversity principles to support their expatriate career progression.

\section{Research limitations/implications}

Longitudinal research is needed to assess how early-career women expatriates' willingness to trust in organisational equality/diversity principles alters as their careers progress, and the effects of any 
changing trust relations on their contributions to organisational strategic objectives. Larger senior female expatriate samples are needed to research links between trust relations and turnover.

\section{Practical implications}

Organisations must weigh up benefits from using transparent expatriate selection processes versus less formal mechanisms, if informal processes are not to undermine espoused equality interventions.

Unconscious bias training should form part of wide-ranging programmes to tackle discrimination. Senior managerial action with embedded accountability is needed.

\section{Originality/value}

Exploring the rhetoric and reality of equality/diversity policy implementation on women comprising a minority expatriate group, this research demonstrates women expatriates' early-career trust in gender equality falls away as they first recognise and then accept diminishing female expatriate senior grade representation and the implications for their expatriate careers. Should turnover result, this could detrimentally affect organisational expatriate gender diversity objectives.

Key words: Diversity, equality, expatriation, gender, trust, women 


\section{Introduction}

Women comprise one-third of international assignees (Santa Fe, 2020) but this figure masks wide sectoral variations. For example, in oil and gas exploration women hold less than $15 \%$ of expatriate positions despite this industry's espoused commitment to increasing female expatriate participation (Shortland, 2016). Although organisations are undertaking selected diversity initiatives in an international context, for example to widen networking opportunities for women (Shortland, 2011) and to lobby for spousal working visas aiding expatriate employment for dual career couples (Permits Foundation, 2020), equality and diversity policies are primarily examined at a domestic level. Global diversity management remains under-studied (Özbilgin et al., 2015). So whether diversity actions such as planning, coordinating, and implementing strategies and policies within multinational operations are functional and achieve their stated aims is relatively unknown. This suggests that we need to understand how female expatriates interpret the effectiveness of the practical implementation of organisational equality and diversity policies in support of their expatriate careers. HR specialists write and disseminate organisational policies (Perkins and Daste, 2007) and thus their views on the value of equality/diversity policy design and its implementation are also pertinent to any investigation into the efficacy of organisational expatriate gender diversity initiatives.

Women expatriates perform roles in multinational organisations that may be characterised as dependent on professionalism and participative management styles to cope with the complexities and uncertainties of transnational business, where "trust is thought to be a more appropriate mechanism for controlling organizational life than hierarchical power" (Sydow, 1998, p.31). The unique contribution of this research is to examine both equality/diversity policy implementation from the perspectives of HR policy implementers and current women assignee recipients to determine whether or not policy is implemented as intended. As part of this picture, consideration of policy recipients' willingness to place 
their trust in this process - a previously unstudied issue in women's expatriation - can potentially assist in better understanding issues surrounding women expatriates' perceptions of organisational support for their expatriate careers as well as contributing to trust theory through an expatriate gender lens. The research thus aims to investigate women expatriates' perceptions of the effectiveness of - and trust in equality/diversity policy implementation to facilitate their expatriate ambitions. Its objectives are to report on the perspectives of Human Resources (HR) policy implementers, and to hear the voices of current women expatriates who, as policy recipients, have personal experiences of equality/diversity policy implementation in supporting their expatriate selection and career progression.

Occupational segregation (including horizontal and vertical dimensions) affects women's appointment to particular jobs and positions within organisational hierarchies. Horizontal segregation refers to where one gender comprises the majority of an industry's workforce. In practice, it results in women being under-represented in sectors and occupations which are most valued by society and which have higher status, prestige and pay (Eurofound, 2017). Vertical segregation refers to limited career progression for a particular minority group with gender inequality denoted by women's concentration in the lower echelons of organisational hierarchies. Horizontal segregation affects vertical segregation the smaller the percentage of women in a profession, the lower their chances of getting to the top of it (Wirth, 2001). Organisations use global working as a talent pipeline (Dragoni et al., 2014) and assignments can present career advantages to those who undertake them (Caligiuri and Colakoglu, 2007; Jokinen, 2010). Expectations of equality in achieving professional goals affect expatriates' job satisfaction, commitment and turnover intentions (McNulty et al., 2013). Hence, if organisations are to increase expatriate gender diversity via equality/diversity management the contributors to horizontal and vertical segregation must be tackled. These include: women's motivations being misconstrued; corporate hesitation or opposition to their expatriation; and host environment receptiveness perceived wrongly as 
dismissive or hostile (Altman and Shortland, 2008). Expatriate selection is generally drawn from a managerial pool (Liu and Wilson, 2001) but women's entry to this is affected by covert barriers such tokenism, exclusion and isolation contributing to an expatriate 'glass ceiling' (Linehan and Scullion, 2001). Women also face a 'glass border', having to convince selectors of their ability to work across geographies (Linehan and Walsh, 1999). These glass structures reinforce each other, creating a doubleglazed effect (Insch et al., 2008).

Women face a number of challenges throughout the expatriate career cycle: they are treated unfairly by organisations in selection; lack or have reduced access to various aspects of on-assignment support; and finally face greater challenges than men on repatriation (Shortland and Altman, 2011). These issues raise potential concerns about the willingness of women to trust their organisations to support their expatriate careers. Yet, despite these hurdles, women are as successful as men on international assignments (Tung, 2004). Indeed, they have been found to be preferred as co-workers (Varma et al., 2006) and to show greater adaptability and more positive attitudes towards locals resulting in them managing others better than their male counterparts (Dallalfar and Movahedi, 1996). It would thus be expected that, once they break into the occupationally segregated male expatriate environment, horizontal segregation should reduce and, as women expatriates thrive, so should they rise up the international career ladder leading to reductions in vertical segregation. It is therefore crucial that organisational equality and diversity policies work in an expatriate context. Our first research question for empirical analysis is therefore:

RQ1: What are HR specialists' views on the alignment of equality and diversity policy implementation with stated organisational intentions to foster gender diversity in expatriation?

Equal opportunities/equality policy strives to ensure equal, consistent treatment of all groups while diversity policy aims to address differences proactively (Jonsen et al., 2010). Diversity 
management presents a clear business case argument: it provides access to a wider talent pool; a workforce representative of its customers; and it harnesses multiple perspectives and capabilities for competitive advantage (Shen et al., 2009). It also highlights an organisation's ethical stance (Kaler, 2001). Problematically, equal opportunities are frequently seen as a burden (Rubery et al., 2003) and so organisations typically adopt short agendas which do not require foresight and longer term investment (Cockburn, 1991). The business case diversity rhetoric can legitimise a gendered status quo (Cassell, 1996), reinforce stereotypes (Robinson, 2007), and justify unfair actions (Noon and Ogbonna, 2001). So, while the headquarters may highlight the economic benefits, subsidiaries may not see the reasons for transposing equality/diversity policies internationally (Ferner et al., 2005). Hence, while policy interventions are laudable, without embedded accountability (Kalev et al., 2006) and top level support (Shen et al., 2009) real change is unlikely. These aforementioned problems thus raise implications linking expatriate gender diversity policy and practice with organisational trust relations.

\section{Trust relations}

Individuals "would have no need or occasion to trust apart from social relationships" (Lewis and Weigert, 1985, p.969). Trust involves a minimum of two participants: a trustor who grants trust and a trustee who receives or obtains trust (Kenning, 2003), and is a central component of effective social structures (Kutsyuruba and Walker, 2016). Developing the analysis of trust relevant to business contexts, Sako (1998, p.89) argues that trust creates an expectation between the actors that each will behave in a mutually acceptable manner: "an expectation that neither party will exploit the other's vulnerabilities". She postulates trust as a mechanism that absorbs interactive complexity and imperfect information: someone who trusts acts as if the trustee's actions are at least to some degree predictable (Rempel et al., 1985). The assumption narrows possible actions, in turn reducing risk or uncertainty that an agent's freedom of choice will not undermine any stated or implied undertaking (Cerna, 2014). 
Sako (1998) models trust relations arranged as a hierarchy: contractual trust, competence trust and goodwill trust, extending Lewis and Weigert's (1985) cognitive, emotional and affective trust model. At the base, 'contractual trust' applies a shared norm of honesty and promise-keeping, experience of which may be accumulated through cognitive processes lubricated by repeated trustortrustee interaction over time. Positioning the trust level on a continuum from low to high may be informed by the level of maturity of knowledge accumulation embedded in particular social relations. At a second level is 'competence trust': empirically verifiable, Sako (1998) argues, by reference to evidence of whether or not the other party to the relationship is capable of doing what it claims it will do. She argues there is a shared understanding between the parties to the relationship of professional conduct and related standards. Enmeshed in emotional trust (Johnson-George and Swap, 1982), the parties rely on the morality of fair dealing manifested in their interactions. Moving through the hierarchy to 'goodwill trust' involves the parties gradually expanding a common cognition as to the nature of social reality and of what constitutes acceptable social exchange procedures within specific contexts, mitigating against the risk of opportunistic behaviour. That is to say the parties' behavioural enactment of trust involves taking a risky course of action on the practical assumption that all parties to a trust relationship in business and, relatedly, employment (i.e. exchange relationship) settings will "act competently and dutifully" (Lewis and Weigert, 1985, p.971). Given an acceptance that social conflict in organisations is as likely as social harmony, behavioural trust is undermined, for example, if a party to a contract withholds a critical piece of information. This may not breach the contract in terms of its letter but could be viewed as doing so in terms of its spirit. Institutionalised trust, therefore, raises questions as to the degree to which those who lead and manage organisations, are seen as trustworthy (Tan and Tan, 2000): can these trustees' behaviour be interpreted by trustors as "fulfilling the spirit of the contract, by demonstrating commitment and fair behaviour" (Sako, 1998, p.90)? 
Women expatriates' perceptions of the implementation of equality/diversity policy are thus suggested not only as an antecedent to their trust in their managers (Connell et al., 2003) but also as a contributor to their willingness to make an emotional 'leap of faith' (Lewis and Weigert, 1985) to support their employers in meeting the competitive objectives of their industry sector (Tyler, 2003). This highlights the utility of Sako's (1998) contractual, competence and goodwill trust hierarchy, which we apply to frame analysis of whether or not organisations deliver equality/diversity policy as contracted, the behaviours of managers to whom policy implementation is entrusted, and whether and how women assignees are willing to exhibit affective commitment to support their firm's organisational strategic objectives, based on willingness to act on the assumption that trust will be reciprocated through support for their international careers. To this end, this study considers what can be gleaned from a comparison of organisational policy statements and the views among HR policy custodians responsible for their implementation, with those of women expatriates interested in international career advancement. By analysing enacted procedures for identifying, selecting, developing, and promoting employees internationally, it assesses whether or not equality and diversity principles match those that are expressly or tacitly espoused by organisational managements and whether female expatriates can and do place their trust in them. Our second question for empirical analysis is therefore:

RQ2: How do female expatriates perceive the effectiveness of organisational equality and diversity policy implementation, trusting it to support their international careers?

\section{Method}

\section{Research context}

At first sight, the selection of the oil and gas exploration sector for a research study into women's trust in equality and diversity policy implementation to support their expatriation might appear incongruous. Exploration typically occurs in remote and challenging locations (Markus, 2015) where masculine host 
country environments with institutionalised gender discrimination can be particularly discouraging to female expatriates (Bader et al., 2018). This background illustrates the scale of the challenge to this industry. Organisational effort to implement equality and diversity policies to engender trust can clearly stand out in this context. Hence, hearing women's views on how relevant such employer actions are to their expatriate selection and career progression can offer pertinent lessons for others attempting to increase expatriate gender diversity, particularly for firms expanding into newly emerging industrial economies. The oil and gas industry is also a large user of expatriate personnel; expatriates comprise $7.8 \%$ of oil and gas firms' workforces, compared with the all-industry average of $2.8 \%$ (Air Inc., 2017), enabling access to viable research samples of female expatriates.

\section{Research design}

The research proposal was presented to a meeting of the UK Oil and Gas Industry Peer Group attended by Human Resources (HR) representatives from 18 oil and gas exploration firms. Two of these HR specialists - International Assignments Managers (IAMs) in their respective firms - agreed for their organisations to participate anonymously. As shown in Table 1, the two firms (given pseudonyms of Oil Co and Gas Co) were of medium size, employing between 6,000-12,000 people globally across 20-30 countries. Women comprised $28-40 \%$ of their global workforces and $8-11 \%$ of their expatriate populations.

\section{Place Table 1 here}

The research used a qualitative, cross-sectional, case study research design and drew upon indepth semi-structured interviews with HR policy implementers and current female expatriates. The case focused on how the implementation of equality and diversity principles supported gender diversity within expatriation in oil and gas exploration. The focus of the interviews with HR specialists and women assignees was framed by Sako's (1998) trust theoretical perspective to try to understand and interpret both parties' expectations of how stated organisational gender diversity objectives were 
addressed through the implementation of organisational policy. By interviewing both HR specialists and women expatriates, the study was able to compare and contrast the participants' views on contractual, competence and goodwill trust dimensions (Sako, 1998). A case study approach was selected as it could address 'how' and 'why' questions in a real-life context with similar and contrasting viewpoints from the policy implementers and recipients supporting the study's internal validity (Yin, 2018).

In-depth, semi-structured interviews drawing upon a series of open-ended questions were considered most appropriate as these enabled the construction of an interview schedule that could be applied consistently to each participant group (HR and female expatriates) but which could be supplemented with follow-up questions in response to replies of particular significance, thereby providing greater flexibility than structured interviews (Bryman and Bell, 2007). The use of semistructured interviews was also considered important as it enabled the hearing of the female expatriate minority voice thereby gaining direct insight into the complex context of women expatriates' careers in this male-dominated environment.

\section{Research materials, protocol and participants}

Both firms had published provision on equal opportunities/equality as well as concise statements on diversity. The key messages were:

"No one should receive less favourable treatment before or during employment on the grounds of gender ... individuals must be recruited, selected, promoted and treated on objective, relevant criteria .... We are committed to diversity and value each individual's opinions." (Oil Co) "As part of our sustained drive for competitiveness and superior performance (we) take a positive approach to equality and diversity. By tapping into the talent and skills available in all groups and communities in the countries in which we operate we underpin the lasting success of our enterprise ... We ensure equality of employment opportunity and equal access to 
development opportunities and use best practice recruitment and selection techniques, which will ensure fair and objective assessments in enabling the choice of the best candidate from a diverse pool." (Gas Co)

Both IAMs agreed to be interviewed and facilitated interview access with 12 other HR specialists (three in Oil Co; nine in Gas Co) who held responsibility for embedding and implementing equality/diversity policy within their specific HR areas of responsibility. Details of the 14 HR staff roles are given in Table 2.

\section{Place Table 2 here}

In the interviews the HR specialists were asked to comment on the main characteristics of their equality/diversity policy and how it was embedded within their firm’s approach to managing international assignments. They were also asked how women's expatriate participation was prioritised, with focus placed on practices used to support women's access to/selection for international mobility. In relation to expatriate career progression, the HR specialists were asked to speak about women expatriates' job levels/grades, and how the equality/diversity policy was embedded in career management from the graduate scheme up to senior talent management planning.

Both IAMs supplied background demographics, assignment types, job grades and functions, and home/host locations for their 93 current female assignees. They asked all of them to participate in the research and 55 (just under 60\%) expressed willingness to be interviewed. Not all could be interviewed within the research access period offered due to business demands and personal schedules and so stratified sampling was undertaken to select representative sub-groups; 26 women expatriates were selected for interview. The assignee interview participants were asked to provide some personal data (age range, ethnicity, and family status) to enhance the understanding of diversity within the female 
expatriate population. Just under half of the assignees were aged over 40, around $80 \%$ were white, approximately three-quarters were partnered, and around one-third had children.

To maintain anonymity employee names were redacted and host country locations (mainly similar for both firms) were categorised regionally. Assignee numeric/alphabetic grades were classified into four groups: senior management; middle management; junior management; and graduate trainees/non-management grades. Around $80 \%$ of the women expatriates were in the middle and junior management grades. There were only two senior-graded expatriate women employed - one in each company. Female assignees mainly undertook long-term assignments of three to five years' duration. Although both firms operated graduate trainee programmes, no female graduates were on international assignment in Oil Co during the research period. The assignees' profiles are summarised in Table 3.

\section{Place Table 3 here}

Gas Co’s HR provided access to one very senior woman expatriate to discuss the content of the assignee interview questions ahead of the interviews taking place with the female expatriates. This was not a pilot study but an open discussion of issues relating to women's participation in expatriation which helped to shape and finalise the interview questions. By the time the series of female expatriate interviews was conducted, this senior woman could not be included as she had left to join another oil and gas firm. In the interviews the female expatriates were asked to identify what they saw as the key features of their company's equality/diversity policy and its implementation. They were also asked to comment on the degree to which they believed/trusted in how the policy was implemented to provide an effective level of support for their own expatriation and for women's international mobility more generally. In addition, they were asked the extent to which - and why - they felt that expatriation was crucial to their development and career progression. They were also asked how the selection process for their current assignment worked, how they achieved their current grade, any barriers and/or facilitators 
experienced in achieving this, and how they could make it known that they wanted to progress upwards in an expatriate career. Finally, they were asked what they saw as helpful actions that their firms could take to assist women in achieving further expatriation opportunities.

The oil and gas industry has a very strong safety culture driving decision-making (Air Inc., 2020) and hence permission to conduct interviews was mandated upon all being carried out on company premises. The interview practicalities involved all HR staff and female current assignees being interviewed separately, in privacy, for approximately an hour, either by telephone (if the individual was abroad) or face-to-face (if in the UK, for instance on leave). Despite these different interview approaches which resulted from location constraints, all interviews followed the same HR or assignee interview protocols respectively (Appendix 1), and the depth and candid nature of responses received were similar. All interviews were recorded and transcribed with permission.

\section{Data analysis and structure}

Theory can provide prior direction for the analysis of qualitative data (Hayes, 1997). In this research study theoretical thematic analysis was undertaken to interpret, organise and describe aspects of diversity and equality in women's expatriation with identified patterns in the HR and assignee interview transcript data coded as emerging thematic concepts (Boyatzis, 1998). Two a priori themes relating to how equality and diversity policies supported female expatriation were used, divided into four categories: application (policy implementation), gender (driving forward women's expatriation), selection (supporting women expatriates' appointments), and career management (advancing women's expatriate careers). One further category - no information - was used to identify instances when policies were unknown/irrelevant.

Two independent coding processes were undertaken to reduce coding drift and improve reliability. These were undertaken using Microsoft Word and NVivo qualitative analysis software. First, 
the a priori themes and categories were identified and highlighted using coloured bars applied to the Microsoft Word text. Emerging concepts were noted using margin notes. After a period of about a month, the transcripts were re-coded afresh using NVivo. This helped to provide a new outlook on the data, reducing the likelihood of recoding simply based on memory from the first thematic coding exercise. Subsequently, the coding from the two methods was compared and any differences in the key themes were rationalised through revisiting the transcripts. Table 4 presents explanations of a priori themes/categories and emerging concepts.

Place Table 4 here

Drawing upon Harrison and Rouse (2014), the data structure for this research is presented diagrammatically in Figure 1. To demonstrate the main HR and assignee findings in relation to the importance of each emerging concept, the percentage of the $14 \mathrm{HR}$ specialists and 26 female expatriates who raised each identified issue is noted in the diagram. Quotations from the HR and assignee participants were tabulated under each category (see Tables 5 and 6 respectively). The importance of each issue raised by the interviewees was evaluated by reviewing the content of the quotations. Reference was also made to the number of individuals citing particular issues to ensure that quotations selected as illustrations reflected the respondent population, not individual concerns.

Place Figure 1 here

Place Tables 5 and 6 here

\section{Findings}

The findings are presented within two sections. Within each, the views of the HR policy implementers and female assignees are examined using a priori categories as sub-headings to signpost the storyline which is drawn from the emerging concepts identified from the interviews. The first section presents data in relation to organisational implementation of equality and diversity policies in support of 
women's expatriation, using data drawn from the application and gender a priori categories. The second section examines how the HR specialists and female expatriate policy recipients perceived the effectiveness of equality/diversity policy implementation in supporting women's selection for expatriation and in furthering their international careers, using data drawn from the selection and career management a priori categories. It was notable from the data analysis that the female expatriates' views differed according to their level of seniority (as presented in Table 6). Each section therefore presents the views of the female expatriates by grade drawing from the lowest, junior, mid- and senior graded personnel as discrete groups. Finally, the findings are summarised with implications for trust identified.

\section{Equality and diversity policy implementation}

Application: To set the scene for the HR perspective on female expatriates' selection and career management within the known masculine environment of oil and gas exploration, it is appropriate to begin with a review of HR's perceptions of the extent to which they see equality/diversity policy implemented in practice globally. This is because expatriate selection and career management in both firms was not managed centrally nor solely by the parent/headquarters organisation and, while the HR function had an input into these activities, it did not control decision-making. In Oil Co line managers based in regional centres working with host country line managers had input into expatriate appointments, and a central talent review process involving the senior management team determined succession planning and career path decisions. In Gas Co functional managers with technical specialist expertise held responsibility for the career development of all employees, expatriates and line managers within their skills set globally and they had the overall say on expatriate appointments.

Although published international assignment policies did not contain specific content relating to equality and diversity, the HR specialists in both firms stated that equality/diversity principles were important and were applied to expatriation. For example: "you wouldn’t make any difference between a 
man and a woman in the role" (L\&D, Oil Co) and "any perceived prejudice ... is absolutely and unequivocally challenged" (FH, Gas Co). Yet, despite these clear statements of intent, policy implementation did not fully deliver gender equality in expatriation outcomes as evidenced by few women holding expatriate roles, especially at senior levels. The HR specialists explained that international roles were primarily filled from horizontally segregated (male) disciplines such as engineering and geoscience, thereby favouring male appointments: "it is the demographic that sways that one" (IAM, Oil Co). Fieldwork was also highlighted as precluding women working offshore in certain countries, limiting the application of equality policy in practice: "through no fault of her own she is a bit less use really" (GSM, Gas Co).

The HR specialists were keen to point out that women did not "want to get something because of tokenism" (IAM, Gas Co) and their firms did not wish to run "the risk of positive discrimination (so would) never particularly target women" (L\&D, Oil Co) and so no positive action was taken. However, they pointed to monitoring efforts being made to support more women gaining early-career expatriate roles: "to change the equilibrium ... we are starting to monitor ... the early and mid-career hires" (FH, Gas Co) by hiring "50-50” (RM, Oil Co) men and women in graduate intakes. Although HR in both firms reported that equality/diversity policy implementation was everyone's responsibility, the lack of specific accountability was highlighted as disadvantageous to progressing women's expatriate representation making this "more difficult ... for a woman" (GSM, Gas Co):

"The cynic in me would say is it lip service? We've got ... lots of initiatives, people track our statistics ... but I just feel that there is an underlying male chauvinism and a cronyism.” (IAM, Gas Co)

Turning to the views of the female assignees, on the whole those in the early stages of their international careers, including many in junior management roles, stated that they thought that equality 
policy was important and was implemented within international mobility, noting "I don't think (the company) discriminates (\#F) or "has actively behaved in any unequal way" (\#O). However, at the junior management level it was notable that organisational equality principles were not fully applied. Some asset head male managers were reported as hesitant to deploy women into field locations in masculine cultures, perceiving these as difficult for women. Examples were also given of women expatriates' managerial authority being undermined, but without such prejudice being tackled by management as suggested by HR policy implementers. This suggested that only lip service was paid to policy implementation:

"One member of the team thinks nothing of saying that he would never work for a woman ... The culture is just incredibly dismissive of working women.” (\#L) The women in the most senior expatriate grades believed that equality/diversity policy implementation failed to support women's expatriation, instead favouring men. They expressed a sense of futility in their firms' efforts:

"I know companies will tell you everybody has got equal opportunity and you nod your head and you go 'yes', but you know that is not true ... And so I think the bigger question is, you have got females coming in, so what do you need to do to make sure they have equal opportunity?" (\#B) They explained that female access to the male culture was restricted by male asset head and line manager perceptions of what women could do, needed to do, and a lack of belief that they had developed the capabilities to operate at the most senior levels:

“I was always told 'you don't look like an engineer'. I am very petite, with long blonde hair, and so I was always seen more as a 'lady' versus an 'engineer' and it is very tough to get over.” (\#B) 
“Having been 'born' at (Gas Co) ... trying to explain ... you are (senior) looking for the next step up when they still have this perception 'I can't believe how much you have developed and how far you have come', there's a subtext. He remembers me as a graduate." (\#S)

Gender: The HR specialists acknowledged that insufficient steps were taken by their firms to address the gender imbalance in expatriation. With no female-dominated functions, a lack of female-friendliness, and perceived underlying male bias, HR reported female disadvantage in the male-dominated environment:

"Until you get a) somebody in place championing it and b) bringing in very clear policies and procedures, and that people are trained up and held accountable ... we are not going to really make any progress.” (HRD, Gas Co)

Diversity policy was highlighted in particular as requiring more promotion, greater understanding and wider awareness of business benefit outcomes in both firms.

The lack of gender balance in the workplace was clear to all of the female expatriates. Those in the graduate and non-management grades at the start of their international careers highlighted their high visibility in comments such as "the assessment centre was six males and me" (\#T) and "there are only two of us" (\#G). While this could potentially have been daunting, some accepted this as a challenge, saying "my competitive instinct was definitely heightened" (\#T): the competitive nature of the industry sharpened their efforts to win what they described as a male game. For others though, women's poor expatriate representation, particularly as observed at higher levels of seniority, was already a matter of concern. They worried "I have not seen many women working on management level" (\#G) and began to articulate why this might be so, indicating that the environment might not prove female-friendly particularly in relation to motherhood: "I guess there will come a point where I decide to start a family and that would be a blocker maybe" (\#J). 
The women in the most senior expatriate grades questioned how expatriate roles in the industry could be more gender-balanced, given the historical and current masculine nature of the industry:

"The vast majority of the jobs come from the more traditionally male-dominated functions, such as engineering, geology, geophysics. So the question is 'how could we try?'.” (\#S)

\section{Expatriate selection and career progression}

Selection: Regarding women's access to expatriate opportunities in the middle grades and at more senior expatriate levels, the HR specialists highlighted the espoused practice of using an open selection process via the portal (intranet) to advertise vacancies: "we should advertise on the website and all opportunities should be up" (RM, Gas Co). In reality though HR acknowledged that this did not always take place and made reference to semi-autonomous region heads who attempted to head-hunt "the best talent ... and resite it within their own region" (IAM, Gas Co). In essence, HR reported that from the mid-grades upwards "selection is actually a misnomer; the vast majority are actually direct appointments" (IAM, Gas Co) and that this affected women expatriates' promotion opportunities when such positions were obtained by a gendered process of "who you knew and networking, and not always ... advertised on the portal" (HRT, Gas Co).

The women assignees on the graduate scheme and in non-management roles reported that selection for expatriate positions hinged upon discussions with their direct line managers. At junior and mid-management levels the women reported expatriate positions usually being posted on the portal, and current female assignees applying for these as part of an open, competitive process ("there was a posting and I applied for it and I got it", \#H; "it was advertised and I applied”, \#A). Once women had reached mid-management expatriate positions though, there were examples of the expatriate selection process appearing to have become gendered to a greater extent, creating challenges for women seeking expatriate roles. Potentially discriminatory practices meant that female expatriates had found themselves 
having to challenge the culture and pursue expatriate opportunities with greater determination than their male colleagues:

"My line manager ... a guy ... made the classic mistake of articulating the assumption that "of course I wouldn't be interested ... because my partner was based here' and I reacted by saying, 'why do you think that? Of course I would be interested'." (\#Z)

Career management: The HR specialists reported that although "internal promotion is ... paramount" (RM, Oil Co) formal career progression mechanisms could be opaque, haphazard and gendered. Women faced career uncertainty and lack of expatriate opportunities particularly at the most senior levels:

"When ... they become more general management ... totally reliant on your network ... you find a lot of women getting up to (mid-grade) level but there are relatively few who manage to break through ... Because we don't have this very structured systematic way of placing people in their next role, you do get black holes emerging." (HRD, Gas Co)

The women assignees also spoke frequently of an opaque and haphazard career management process that seemed to be based upon favouritism and cultivating relationships with male superiors "through informal channels" (\#I) in order to be considered. This generated career uncertainty and perceptions of restricted opportunities for women:

“It wasn't about what work you do or how many barrels you've found, it was did your boss like you? ... How well does your boss know you?” (\#F)

Perhaps not surprisingly, some junior management had lost faith in their organisation's espoused equality-based career management process (“they are not very good with managing the next step", \#K), believing it instead to be gendered, favouring men:

"I don't believe ... equal opportunity for women ... Look at our management composition for proof in key roles...not many women beyond lower middle management." (\#K) 
It was also notable that once women had reached mid-management expatriate positions, they saw these as the limit of female expatriate career progression - there were so few women at senior levels that further promotion was simply not considered feasible:

"The percentage of women who are in ... roles that go international, and the percentage that have done ... you have to cut it off at (mid-management)." (\#M)

They called for greater company effort from the very top of the organisation to promote equality and diversity in expatriation:

"They have got to see the benefit of why you need a diverse organisation and the benefits ... it needs to start from the top.’(\#E)

Unsurprisingly, given the women's apparent loss of trust in their firms to enable them to progress further in their international careers, this led senior female expatriates to consider alternative career options with different employers:

"There are very different perceptions on what females need to do as opposed to what males need to do to get to the next level ... I don't see any advancement past where I am now. External, I'd definitely look.” (\#B)

\section{Summary}

While HR specialists stated that equality/diversity principles were applied and that efforts were being made to improve female representation by recruiting more women into the internationally mobile graduate grades, they candidly acknowledged that their firms' policies did not fully achieve stated objectives. This was primarily due to lack of specific accountability for policy implementation and adherence to the stated principles of open advertising. These issues were compounded by responsibilities for expatriation management being dispersed through a range managerial levels and functional areas across global operational locations. The articulated contractual difficulties in applying equality/diversity policy in certain locations, the persistence of haphazard and opaque approaches to HR practices, 
underpinned by a masculine and potentially gender-biased culture not only combined to stymie HR's good intentions to implement equality/diversity policy effectively in pursuit of expatriate gender diversity objectives but also suggest that conditions for building contractual, competence and goodwill trust (Sako, 1998) are likely to be jeopardised. This highlights the importance of hearing women assignees' voices.

Women assignees began their international careers with trust in equality even though they recognised their minority expatriate status. However, as their careers progressed and they experienced gendered selection processes, opaque and haphazard career management, and observed the lack of gender diversity in more senior expatriate roles, so their concerns grew over delivery of equality/diversity policy. Women expatriates' disillusionment in organisational support for their international career progression continued to increase as they gained seniority and experienced further instances of unequal treatment. The few who had made it to the top grades no longer believed in their organisations' equality rhetoric given its divorce from their experience of gendered selection and career management processes. Asset head and line manager discriminatory actions highlighted breaches in contractual and competence trust (Sako, 1998). These finally led to senior women expatriates losing goodwill trust (Sako, 1998) in their firms to support their international careers, resulting in potential turnover intentions.

\section{Discussion}

This research study set out to investigate women expatriates' perceptions of - and willingness to trust in - the effectiveness of organisational implementation of equality and diversity policy in support of their international careers. Mixed messages emerged. Published policy statements are unequivocal: there is equality of opportunity, and diversity is welcomed, and this is driven by the need to be competitive. Reading these, women investing their career potential could feel reassured. Evidence that expatriate opportunities are subject to best practice selection techniques, namely being advertised and open to 
competitive application (Harris, 2002) should also provide women with encouragement and a sound basis upon which they could build contractual trust in their employers (Sako, 1998). Yet, the HR policy custodians adopt a more ambivalent, even negative, tone in some of their candid interview comments. Thus, although at one level, good intentions continue to be expressed in ruling out gender-based discrimination, below the surface the observable culture (labelled as displaying 'chauvinism' and 'cronyism'), sits at odds with the rhetoric of positive diversity statistics (Kramer and Cook, 2004). Objectively, this is confirmed by female expatriates not progressing significantly beyond the middle ranks - the glass ceiling and border being firmly double glazed into place (Insch et al., 2008). Indeed, drawing upon the perceptions of female expatriates, grouped by organisational 'generations' from earlycareer to seasoned operator, these glass ceilings and borders show little porosity. For example, while early-career female expatriates in the sample express their current situation as not subject to discrimination, once they look forward and reflect, based on the observable reality of benchmark colleagues, then stereotyping constraints appear to surface - leading to contractual mistrust (Sako, 1998) and pared back expectations as to their likely fate once family and related considerations enter the picture (Lanaj et al., 2018).

There is also evidence from this study that female expatriates who have achieved some degree of expatriate career progression suffer discouragement epitomised by the face of glass ceilings and borders: when glancing upwards, women see the majority not diversely reflective of a demography that could create conditions for further female expatriate career progression. In some instances more stark reminders of the 'boys club' culture emerge in reflections on organisational omission to tackle open comments among male peers that suggest that they have not understood (or refuse to acknowledge) that the appointment of women expatriates to lead them is based upon their capability. This raises theorisation of the prospect that these institutionalised manifestations of unequal treatment will, as 
women expatriates' careers evolve over time, harm their propensity to place competence trust (Sako, 1998) in their managers to comply with organisational policy, even if the trust relations are not totally broken (Luhman, 2000).

In this study, respondents at senior levels carry memories that demonstrate recognition of male managerial limitations applied to their scope to break through the embedded glass structures. They speak with a sense of futility that positive change can be achieved. Individuals whose expectations have not been satisfied by a manager may adopt a distrusting attitude towards that person and, by extension, the organisation in future, giving rise to the social dilemma of the extent to which they will reward their firm in terms of their performance (Van Lange et al., 2017). Hence, by using by trust relations as a theoretical frame, it would be predicted that if women professionals' propensity to invest competence trust (Sako, 1998) in their management to assist their access to expatriate careers is undermined, they will no longer reward their employer with their goodwill trust (Sako, 1998). This suggests that they will no longer prioritise or reward organisational interests, given their understanding that any such actions are unlikely to be reciprocated through active support for their career progression (Kutsyuruba and Walker, 2016).

Gas Co’s most senior female assignee faced a gendered subtext querying her capabilities, aligned with research that suggests that women have to prove their worth and press for career moves to a greater extent than men (Linehan and Walsh, 1999). Oil Co's most senior assignee's conclusion was that equal opportunity was 'not true' and her future was 'external'. This indicates that, in the most extreme cases, the loss of women expatriates' trust in equality/diversity policy implementation might result in them leaving their firms to pursue alternative career opportunities. Indeed, Gas Co's HR specialists reported that its most senior female expatriate who was consulted on the interview schedule left because she could not foresee support for her own or for women's senior expatriate career paths in general. 
It is acknowledged that stating turnover intentions is both a private and sensitive matter for employees and an area that HR specialists also may not wish to reveal in any detail if it might suggest poor policy and practice outcomes. As such is it unsurprising that only sporadic citations relating to turnover intentions were recorded in the interviews. While there were very few senior women expatriates employed by the two firms in this study, from the evidence gained and by using theory to predict potential outcomes, it is suggested that when women expatriates lose trust in their firms to enact equality/diversity principles they will pursue expatriate careers elsewhere. If the very few women who reach the top leave then, by default, this will increase vertical segregation and have negative consequences for organisational diversity objectives. This indicates that further research in this sensitive area would be especially important because if senior level female expatriate turnover becomes widespread it can generate an atmosphere of distrust undermining the very core of organisational values (Tschannen-Moran, 2014). This leads to the following research proposition:

RP1: Female expatriate turnover resulting from loss of trust in organisational equality/diversity policy implementation will compound women's low expatriate representation thereby undermining organisational expatriate gender diversity objectives.

A further critical discussion area relates to the difference in emphasis placed on various aspects of equality/diversity policy implementation by HR specialists and female assignees. As highlighted in Figure 1, although the majority of HR (86\%) and women expatriates (77\%) interviewed commented on the male-dominated nature of their organisations, it is interesting that only $36 \%$ and $15 \%$ respectively believed diversity policy to be an important intervention. Indeed, $36 \%$ of HR specialists reported it as irrelevant and 7\% believed it to be widely unknown. For equal opportunities policy, the figures were $29 \%$ and $14 \%$ respectively. Although HR are known to be guardians of organisational policy with responsibility for writing it and promoting consistency in implementation approaches (Perkins and 
Daste, 2007), lack of accountability in policy implementation globally proved an insurmountable hurdle for the HR specialists in this study, helping to explain these findings. In comparison, none of the female assignees reported diversity policy and only $4 \%$ reported equal opportunities policy as unknown or irrelevant to them. This may suggest that women expect - and potentially trust - such organisational policies to contractually underpin their employment even if they do not necessarily hold great store in these making a difference to their expatriate career outcomes.

With regard to the implementation of equality policy in supporting women expatriates' selection and international career management, there were again some interesting differences in issues reported by the HR specialists and female expatriate interviewees. Most notably $58 \%$ of the female expatriates reported the selection process as gendered, with $38 \%$ noting career management to result in a lack of international opportunities for women. The figures for HR were 7\% and zero respectively. These findings may highlight the lack of awareness by HR of actions taken at local level by host country decision-makers when implementing equality policy, reflecting a tension between policy intention and delivery (Perkins and Daste, 2007). These findings also potentially raise the issue of competence trust (Sako, 1998) - namely are these host country decision-makers capable of fulfilling policy delivery aligned with what policy indicates they should do?

\section{Implications for practice}

While the HR function may aim to promote and fulfil organisational equality/diversity objectives, in this research study the HR specialists reported feeling powerless in implementing policy as they were thwarted by the organisational line that everyone had responsibility but no one was held specifically accountable for equality/diversity outcomes. Good intentions were undermined by the lack of top management action. This leads to specific accountability being required in practice. Articulation of equal opportunity and diversity principles must be supported by action championed at senior central and 
local levels to increase expatriate gender diversity and women's international career progression. Relevant individuals such as line and functional managers could be appraised on equality/diversity objectives to address the need for accountability. For example, initiatives to promote senior female expatriate representation might include positive action at regional/local level such as ensuring interview opportunities for senior female expatriates, an intervention that could be monitored with outcomes evaluated.

In respect of women's access to expatriation more generally, research demonstrates that open, transparent and formal processes for expatriate selection/succession planning are likely to assist women to secure expatriate roles (Harris, 2002). While this approach should be prioritised, this can be ineffective if undermined by informal relationship building. Notwithstanding this, mentors, role models, sponsors and networks can all assist women to access international career opportunities, although in male-dominated environments women can experience exclusion from such forms of support (Linehan and Scullion, 2001). Organisations should therefore consider carefully whether to enact formal and open selection processes or invest in support initiatives such as networking interventions for women, but taking care that the latter do not reinforce male camaraderie at the expense of gender inclusivity (Shortland, 2011).

While effort to support a gender balance in early-career stages is laudable, a cultural shift that embraces and respects women's contributions at all levels throughout an organisation will require specific, embedded accountability. Managers at all levels may benefit from investment in unconscious bias training to recognise their responsibilities towards those whose careers they influence, and to help them to be more open to practising unbiased behaviours more likely to foster trust between women assignees and their employing organisations. Once again though, care is needed in the use of this intervention. Currently fashionable as a "psychology-led diversity initiative" (Noon, 2018, p.199), it can 
simply normalise and cement into place unconscious behaviours, embedding bias even further, unless it is delivered as part of an all-encompassing and continuous programme to tackle discrimination (Williamson and Foley, 2018). Organisations wishing to implement unconscious bias training are advised to make clear the dangers of normalising bias, structure training content around actual workplace circumstances, and ensure that participants have action-oriented strategies to effect change. Rigorous evaluation of training is also needed (Emerson, 2017).

\section{Limitations and future research directions}

This cross-sectional research study was set within two oil and gas organisations. Further research across a wider range of industries could provide valuable comparisons. The research focused on the views of female expatriates and the HR custodians of equality/diversity policy; no access to line/functional managers was available to cross-check their implementation of policy and perceptions of their trustor/trustee relationships. Further research is therefore needed to address this. This study also focused solely on one minority expatriate group - women; further research into the career experiences of other expatriate minorities (for example, ethnic, religious, LGBT minorities) is required to broaden our understanding of how expatriate equality/diversity policy plays out in practice. Further research could also usefully compare the views of male and female expatriates on the effectiveness of equality and diversity policies in supporting minorities' access to expatriate positions.

Trust theory calls for attention to the sense that willingness to take risks evolves over time through interactive reciprocal social exchange between trustors and trustees. The analysis in this paper extends this theorising by reference to evidence from female expatriates to suggest that, as they gain experience with seniority during their expatriate career progression, their encounters with organisational managements can lead to a change in trust-risk propensity; namely as female expatriates' trust falls away, so there is a deterioration in their willingness to make risky career choices involving remaining within the organisation that has damaged their trust. Once women assignees lose trust in their 
organisations' equality and diversity objectives it would be predicted that firms' expatriate gender diversity objectives will be undermined as they seek to further their careers in environments more supportive of their minority status. This aspect could be further informed by longitudinal research following the experiences of early-career women expatriates as they progress their international careers. In this study the two case study firms' female expatriates were primarily in the mid-grades; larger samples of those in higher levels of seniority would also be pertinent to research potential effects of loss of trust on turnover intentions and actions. To study any gendered outcomes of expatriate turnover in depth, it would have been helpful to have had access to HR information on expatriate turnover (ideally broken down by gender) but this was not available. Further research could therefore usefully analyse expatriate turnover data for different seniority levels for both male and female assignees. The indeterminate nature of the employment relationship (Marsden, 1999) suggests that consideration of trust requires attention to the role of individual employee agency in cooperating to a greater or lesser extent with corporate intentions. Enduring features of ordinary experiences such as local understandings shape individual agency (Gubrium and Holstein, 1995). Further research might thus address how female expatriates draw upon their own day-to-day equality/diversity conclusions in taking control and proactively shaping more favourable career outcomes for themselves within or external to their current firms.

\section{Concluding remarks}

Despite espoused policy promising equality and welcoming diversity, organisational practice can fall short of this ideal resulting in women experiencing disadvantage as they seek to access and progress in expatriate careers. As women advance within internationally mobile roles, they increasingly lose faith in the implementation of equality and diversity policy, leading to a loss of trust in their organisations to support them in their expatriate careers. As a consequence, it is predicted that this may result in 
women's unwillingness to continue to provide full cooperation, particularly given articulated organisational recognition that reaching the mid-grades will likely be the best that most women expatriates will achieve. Should loss of women's trust in equality/diversity policy implementation result in turnover, this will reduce women's share of expatriate roles, undermining organisational efforts to increase expatriate gender diversity.

\section{References}

Air Inc. (2017), 2017 Mobility Outlook Survey, Air Inc, Cambridge, MA.

Air Inc. (2020), Mobility Outlook Survey, Air Inc, Cambridge, MA.

Altman, Y. and Shortland, S. (2008), "Women and international assignments: Taking stock - a 25 year review", Human Resource Management, Vol. 47 No. 2, pp.199-216.

Bader, B., Stoermer, S., Bader, A.K. and Schuster, T. (2018), "Institutional discrimination of women and workplace harassment of female expatriates: evidence from 25 host countries", Journal of Global Mobility, Vol. 6 No. 1, pp.40-58.

Boyatzis, R.E. (1998), Transforming Qualitative Information: Thematic Analysis and Code Development, Sage Publications, London.

Bryman, A. and Bell, E. (2007), Business Research Methods, Oxford University Press, Oxford.

Caligiuri, P.M. and Colakoglu, S. (2007), “A strategic contingency approach to expatriate assignment management", Human Resource Management Journal, Vol. 17, No. 4, pp. 393-410.

Cassell, C. (1996), “A fatal attraction? Strategic HRM and the business case for women's progression at work", Personnel Review, Vol. 25 No. 5, pp.51-66.

Cerna, L. (2014), “Trust: What it is and Why it Matters for Governance and Education”, OECD Education Working Papers, No. 108, OECD Publishing, Paris, available at: http://dx.doi.org/10.1787/5jxswcg0t6wl-en (accessed 30 December 2019). 
Cockburn, C. (1991), In the Way of Women: Men's Resistance to Sex Equality in Organizations, Macmillan, Basingstoke.

Connell, J., Ferres, N. and Travaglione, T. (2003), "Engendering trust in manager-subordinate relationships: Predictors and outcomes", Personnel Review, Vol. 32 No. 5, pp.569-587.

Dallalfar, A. and Movahedi, S. (1996), "Women in multinational corporations: Old myths, new constructions and some deconstruction", Organization, Vol. 3 No. 4, pp.546-559.

Dragoni, L., Oh, I.S., Tesluk, P.E., Moore, O.A., VanKatwyk, P. and Hazucha, J. (2014), “Developing leaders' strategic thinking through global work experience: the moderating role of cultural distance", Journal of Applied Psychology, Vol. 99 No. 5, pp.867-882.

Emerson, J. (2017), “Don't give up on unconscious bias training - make it better", Harvard Business Review, Vol. 28 No. April, available at: https://shpr.legislature.ca.gov/sites/shpr.legislature.ca.gov/files/Emerson\%20\%20Unconscious\%20Bias\%20Training.pdf (accessed 26 March 2020).

Eurofound (2017), "Segregation", available at: https://www.eurofound.europa.eu/observatories/eurwork/industrial-relations-dictionary/segregation (accessed 30 December 2019).

Ferner, A., Almond, P. and Colling, T. (2005), "Institutional theory and the cross-national transfer of employment policy: The case of 'workforce diversity' in US multinationals", Journal of International Business Studies, Vol. 36 No. 3, pp.304-321.

Gubrium, J.F. and Holstein, J.A. (1995), "Individual agency, the ordinary, and postmodern life", The Sociological Quarterly, Vol. 36 No. 3, pp.555-570. 
Harris, H. (2002), “Think international manager, think male: Why are women not selected for international management assignments?", Thunderbird International Business Review, Vol. 44 No. 2 , pp.175-203.

Harrison, S.H. and Rouse, E.D. (2014), “Let's dance! Elastic coordination in creative group work: A qualitative study of modern dancers”, Academy of Management Journal, Vol. 57 No. 5, pp.1256-1283. Hayes, N. (1997), “Theory-led thematic analysis: Social identification in small companies” in Hayes, N. (Ed.), Doing Qualitative Analysis in Psychology, Psychology Press, Hove, pp. 93-115.

Insch, G.S., McIntyre, N. and Napier, N.K. (2008), “The expatriate glass ceiling: The second layer of glass", Journal of Business Ethics, Vol. 83 No.1, pp.19-28.

Johnson-George, C. and Swap, W.C. (1982), "Measurement of specific interpersonal trust: Construction and validation of a scale to assess trust in a specific other", Journal of Personality and Social Psychology, Vol. 4 No. 6, pp.1306-1317.

Jokinen, T. (2010), "Development of career capital through international assignments and its transferability to new contexts", Thunderbird International Business Review, Vol. 52 No. 4, pp.325-336. Jonsen, K., Maznevski, M.L. and Schneider, S.C. (2010), “Gender differences in leadership - believing is seeing: Implications for managing diversity", Equality, Diversity and Inclusion: An International Journal, Vol. 29 No. 6, pp.549-572.

Kaler, J. (2001), “Diversity, equality, morality”, in Noon, M. and Ogbonna, E. (Eds.), Equality, Diversity and Disadvantage in Employment, Palgrave, Basingstoke, pp.51-64.

Kalev, A., Dobbin, F. and Kelly, E. (2006), "Best practices or best guesses? Assessing the efficacy of corporate affirmative action and diversity policies", American Sociological Review, Vol. 71 No. 4, pp.589-617.

Kenning, P. (2003), Customer Trust Management, Deutscher Universitats-Verlag, Wiesbaden. 
Kramer R.M. and Cook, K.S. (2004), Trust and Distrust in Organizations: Dilemmas and Approaches, Russel Sage Foundation, New York, NY.

Kutsyuruba, B. and Walker, K.D. (2016), “The destructive effects of distrust: Leaders as brokers of trust in organizations", in Normore, A.H. and Brooks, J.S. (Eds.), The Dark Side of Leadership: Identifying and Overcoming Unethical Practice in Organizations, Emerald Group Publishing, Bingley, pp.133-154. Lanaj, K., Kim, P.H., Koopman, J. and Matta, F.K. (2018), “Daily mistrust: A resource perspective and its implications for work and home”, Personnel Psychology, Vol. 71 No. 4, pp.545-570.

Lewis, J.D. and Weigert, A. (1985), “Trust as a social reality”, Social Forces, Vol. 63 No. 4, pp.967985.

Linehan, M and Scullion, H. (2001), "European female expatriate careers: Critical success factors", Journal of European Industrial Training, Vol.25 No. 8, pp.392-418.

Linehan, M. and Walsh, J.S. (1999), "Senior female international managers: Breaking the glass border”, Women in Management Review, Vol. 14 No.7, pp.264-272.

Liu, J. and Wilson, D. (2001), “The unchanging perception of women as managers”, Women in Management Review, Vol. 16 No.4, pp.163-173.

Luhman, N. (2000), Vertrauen. Ein Mechanismus der Reduktion sozialer Komplexitaet, Enke, Stuttgart. Markus, U. (2015), Oil and Gas: The Business and Politics of Energy, Palgrave, London.

Marsden, D. (1999), A Theory of Employment Systems, Oxford University Press, Oxford.

McNulty, Y., De Cieri H. and Hutchings, K. (2013), "Expatriate return on investment in the Asia Pacific: An empirical study of individual ROI versus corporate ROI”, Journal of World Business, Vol. 48 No.2, pp.209-221.

Noon, M. (2018), "Pointless diversity training: Unconscious bias, new racism and agency", Work, Employment and Society, Vol. 32 No.1, pp.198-209. 
Noon, M. and Ogbonna, E. (2001), “Introduction: The key analytical themes”, in Noon, M. and Ogbonna E. (Eds.), Equality, Diversity and Disadvantage in Employment, Palgrave, Basingstoke, pp.114.

Özbilgin, M.F., Tatli, A. and Jonsen, K. (2015), Global Diversity Management: An Evidence-Based Approach, Palgrave, London.

Perkins, S.J. and Daste, R. (2007), "Pluralistic tensions in expatriating managers", Journal of European Industrial Training, Vol. 31 No. 7, pp.550-569.

Permits Foundation (2020), "Enabling dual careers in the global workplace”, available at: https://www.permitsfoundation.com (accessed 11 May 2020).

Rempel, J.K., Holmes, J.G. and Zanna, M.P. (1985), “Trust in close relationships”, Journal of Personality and Social Psychology, Vol. 49 No. 1, pp.95-112.

Robinson, G. (2007), "Equal opportunities and managing diversity”, in Bloisi, W. (Ed.), An Introduction to Human Resource Management, McGraw-Hill Education, Maidenhead, pp.361-398.

Rubery, J., Humphries, J., Fagan, C., Grimshaw, D. and Smith, M. (2003), "Equal opportunities as a productive factor", in Burchell, B., Deakin, S., Michie, J. and Rubery. J. (Eds.), Systems of Production: Markets, Organisations and Performance, Routledge, London, pp.236-262.

Sako, M. (1998), "Does trust improve business performance?” in Lane, C. and Bachmann, R. (Eds.), Trust Within and Between Organizations, Oxford University Press, Oxford, pp.88-117.

Santa Fe Relocation (2020), Revision - Mobility through the Looking Glass, Santa Fe Relocation, London.

Shen, J., Chanda, A., D’Netto, B. and Monga, M. (2009), "Managing diversity through human resource management: An international perspective and conceptual framework", The International Journal of Human Resource Management, Vol. 20 No. 2, pp.235-251. 
Shortland, S. (2011), "Networking: A valuable career intervention for women expatriates?”, Career Development International, Vol. 16 No. 3, pp.271-292.

Shortland, S. (2016), “The purpose of expatriation: why women undertake international assignments”, Human Resource Management, Vol. 55 No. 4, pp.655-678.

Shortland, S. and Altman, Y. (2011), "What do we really know about corporate career women expatriates?", European Journal of International Management, Vol. 5 No. 3, pp.209-234.

Sydow, J. (1998), "Understanding the constitution of interorganizational trust”, in Lane, C. and Bachmann, R. (Eds.), Trust Within and Between Organizations, Oxford University Press, Oxford, pp. 31-63.

Tan, H.H. and Tan, C.S. (2000), "Toward the differentiation of trust in supervisor and trust in Organisation”, Genetic, Social, and General Psychology Monographs, Vol. 126 No. 2, pp.241-260. Tschannen-Moran, M. (2014), Trust Matters: Leadership for Successful Schools, Jossey Bass, San Francisco, CA.

Tung, R.L. (2004), “The model global manager?”, Organizational Dynamics, Vol. 33 No. 3, pp.243253.

Tyler, T.R. (2003), “Trust within organisations”, Personnel Review, Vol. 32 No.5, pp.556-568. Van Lange, P.A.M., Rockenbach, B. and Yamagishi, T. (2017), Trust in Social Dilemmas, Oxford University Press, Oxford.

Varma, A., Toh, S.M. and Budhwar, P. (2006), "A new perspective on the female expatriate experience: The role of host country national categorization", Journal of World Business, Vol. 41 No. 2, pp.112-120. Williamson, S. and Foley, M. (2018), “Unconscious bias training: The 'silver bullet' for gender equity?", Australian Journal of Public Administration, Vol. 77 No. 3, pp.355-359. 
Wirth, L. (2001), "Women in management: Closer to breaking through the glass ceiling?", in Loutfi, M.F. (Ed.), Women, Gender and Work: What is Equality and How Do We Get There?, International Labour Organization, Geneva, pp.239-250.

Yin, R.K. (2018), Case Study Research and Applications - Design and Methods, Sage, Los Angeles, CA. 


\section{Appendix 1: HR and assignee interview protocols}

\section{HR and International Assignment Manager interview questions}

1. What do you see as the main hallmarks/features/characteristics of your company's diversity/equal opportunities policy? How is it applied to short-term, commuter, rotational and long-term assignments? Examples?

2. How do you make women's participation as assignees a priority? Specific policies/initiatives to increase the \% of women expatriates? Examples?

3. Any action taken by oil and gas sector as a whole (e.g. via oil and gas peer group) to encourage women to take up expatriate roles? Please explain.

4. Current job roles/levels/grades/functions/occupations of women expatriates? Is this profile changing? How/why? Examples? Explain.

5. What are the stages in the expatriate selection process? Who is involved and how does the process operate? How is available internal talent matched to roles? Problems/difficulties? How are these managed?

6. Which elements of the selection process facilitate women's expatriation? Which impede it? Changes to the selection policy and practices over the past five years? Has this resulted in increased numbers of women assignees? Figures (numbers; \%)? Examples: who has benefited and how?

7. Please describe how the graduate recruitment intake process works. What do you do to make/help your firm appeal to women? How many female and male graduates do you take each year? Is the number of women increasing? Can you comment on trends over the past five years? Please comment on the diversity of the graduate intake - gender, ethnicity, age, marital status, etc. Is this changing at all - any explanations for this? 
8. What career development/talent planning initiatives do you have? Please address from junior through to senior level grades. What sponsor arrangements do you have? Explain.

9. What networking opportunities are there for women expatriates? Explain.

10. How is equal opportunity/diversity policy embedded within: the expatriate assignment selection process, expatriate training programme, the international assignment policies used to support international mobility, the annual performance and development reviews, the expatriate career development programme, the international assignment career path and career management programmes, the graduate recruitment programme and the deployment of graduates on international assignments?

11. Any changes to the career development policies, and sponsor and network support over the past five years? Have these resulted in increased numbers of women assignees? Figures (numbers; $\%)$ ? Examples: who has benefited and how?

12. Other policies/initiatives that support women's participation as expatriates? Describe/give examples.

13. Is there anything else you would like to add in respect of women's expatriate participation?

\section{Assignee interview questions}

1. What do you see as the main hallmarks/features/characteristics of your company's diversity/equal opportunities policy? How do you see it implemented/applied to your type of assignment (short-term, commuter, rotational, long-term)?

2. How important to you were gender-related policies in enabling you to participate in your current expatriate assignment? Please comment on the equal opportunities policy (compliance with legislation) and the diversity policy (accommodating differences). 
3. To what extent do you feel/believe/trust that your organisation applies its equality/diversity policies to make women's participation as assignees a priority? Please give examples of policy implementation - draw from your own experience and what you see of women's expatriate careers more generally. Can you comment on your own firm and in the sector more generally if possible?

4. To what extent do you believe that going on an international assignment is crucial to:

- Your development?

- Your career progression?

5. What is your current job role/level/grade/function/occupation? You are now in grade _.

- How do you get up to the next grade?

- How long do you think this will take?

- How far do you feel obstructed in moving up?

6. What career development/talent planning initiatives are there? How will you make it known:

- That you would like another expatriate assignment?

- Where you would like to go (or not to go)?

- What role/job you would like?

7. How did you make it known that you were interested in taking up your current expatriate assignment? How did you hear about the vacancy for your current assignment?

8. How did the selection process operate for your current assignment? Formally according to process - in open/transparent manner? Informally - in closed/not transparent manner? During the selection process for your current assignment, who was involved/had a say in the selection decision? Explain. If applicable, would you describe the graduate recruitment process as 'femalefriendly'? Explain. 
9. Any female company staff involved in your selection, career management, annual performance and development reviews? Explain.

10. Do you have a sponsor? If so, how does your sponsor support you in your international assignment?

11. What are your views on networking to support women's expatriate careers?

12. How is equal opportunity/diversity policy embedded within: the expatriate assignment selection process, expatriate training programme, the international assignment policies used to support international mobility, the annual performance and development reviews, the expatriate career development programme, the international assignment career path and career management programmes, the graduate recruitment programme and the deployment of graduates on international assignments?

13. How could (should?):

a. The oil and gas exploration and production industry be made more attractive to women?

b. International assignments be made more 'female friendly'?

c. Your employer better support women expatriates through equality/diversity policy and practice?

14. Is there anything else you would like to add? 
Table 1: Company background

\begin{tabular}{lll}
\hline & Oil Co & Gas Co \\
\hline \multicolumn{3}{c}{ Company background } \\
Countries of operation & 20 & 30 \\
Employees worldwide & 12,000 & 6,000 \\
Women as \% of global workforce & $40 \%$ & $28 \%$ \\
Expatriates as \% of global workforce & $3 \%$ & $10 \%$ \\
Women as \% of expatriate population & $8 \%$ & $11 \%$ \\
Women expatriates & 27 & 66 \\
\hline
\end{tabular}

Table 2: HR interviewees' roles and responsibilities

\begin{tabular}{ll}
\hline Oil Co's HR interviewees & Gas Co's HR interviewees \\
\hline International Assignments Manager (IAM) & International Assignments Manager (IAM) \\
Learning and Development (L\&D) & Graduate Scheme Manager (GSM) \\
Resourcing Manager (RM) & Resourcing Manager (RM) \\
HR East Asia (HREA) & Function Head (FH) \\
& Learning and Development (L\&D) \\
& Training (HRT) \\
& Development (HRD) \\
& Recruitment Manager (HRR) \\
& Performance Manager (PM) \\
& Training and Development (T\&D) \\
\hline
\end{tabular}


Table 3: Female expatriate interviewee profiles

\begin{tabular}{|c|c|c|c|c|c|c|c|c|c|}
\hline $\begin{array}{c}\text { Participant } \\
\text { letter }\end{array}$ & $\begin{array}{l}\text { Sending } \\
\text { location }\end{array}$ & $\begin{array}{c}\text { Host } \\
\text { location }\end{array}$ & $\begin{array}{l}\text { Assignment } \\
\text { type }\end{array}$ & Occupation & $\begin{array}{c}\text { Management } \\
\text { grade/ } \\
\text { Graduate } \\
\text { scheme } \\
\end{array}$ & $\begin{array}{c}\text { Age } \\
\text { range }\end{array}$ & Ethnicity $^{1}$ & $\begin{array}{c}\text { Partnered } \\
\text { Single } \\
\text { Divorced/ } \\
\text { Widowed } \\
\end{array}$ & $\begin{array}{c}\text { Number of } \\
\text { children }\end{array}$ \\
\hline \multicolumn{10}{|c|}{ Oil Co } \\
\hline \#A & $\begin{array}{l}\text { Western } \\
\text { Europe }\end{array}$ & East Asia & Long-term & Engineer & Middle & $40-44$ & White & Partnered & 1 \\
\hline \#B & $\begin{array}{l}\text { North } \\
\text { America }\end{array}$ & Central Asia & Long-term & Engineer & Senior & $50+$ & White & $\begin{array}{l}\text { Divorced/ } \\
\text { Widowed }\end{array}$ & \\
\hline$\# \mathrm{C}$ & $\begin{array}{l}\text { Western } \\
\text { Europe }\end{array}$ & North Africa & Rotation & Geologist & Junior & $30-34$ & White & Partnered & \\
\hline \#D & $\begin{array}{l}\text { Western } \\
\text { Europe }\end{array}$ & East Asia & Long-term & Geologist & Junior & $30-34$ & White & Partnered & 1 \\
\hline$\# \mathrm{E}$ & East Asia & $\begin{array}{l}\text { Western } \\
\text { Europe }\end{array}$ & Long-term & Human Resources & Middle & $35-39$ & $\begin{array}{l}\text { Asian - } \\
\text { Indian }\end{array}$ & Single & \\
\hline$\# \mathrm{~F}$ & $\begin{array}{c}\text { North } \\
\text { America }\end{array}$ & East Asia & Long-term & Geophysicist & Junior & $35-39$ & White & Partnered & \\
\hline$\# \mathrm{G}$ & East Asia & $\begin{array}{c}\text { North } \\
\text { America }\end{array}$ & Long-term & Health and Safety & $\begin{array}{c}\text { Non- } \\
\text { management }\end{array}$ & $30-34$ & $\begin{array}{l}\text { Asian - } \\
\text { Other }\end{array}$ & Single & \\
\hline$\# \mathrm{H}$ & $\begin{array}{c}\text { North } \\
\text { America }\end{array}$ & $\begin{array}{l}\text { Western } \\
\text { Europe }\end{array}$ & Long-term & $\begin{array}{l}\text { Information } \\
\text { Management }\end{array}$ & Junior & $50+$ & White & $\begin{array}{l}\text { Divorced/ } \\
\text { Widowed }\end{array}$ & 2 \\
\hline \multicolumn{10}{|c|}{ Gas Co } \\
\hline$\# \mathrm{I}$ & $\begin{array}{l}\text { Western } \\
\text { Europe }\end{array}$ & Caribbean & Long-term & Geologist & Junior & $40-44$ & White & Partnered & 3 \\
\hline$\# \mathbf{J}$ & $\begin{array}{l}\text { Western } \\
\text { Europe }\end{array}$ & $\begin{array}{c}\text { North } \\
\text { America }\end{array}$ & Short-term & Graduate Trainee & Graduate & $25-29$ & White & Partnered & \\
\hline$\# \mathrm{~K}$ & Australasia & West Africa & Long-term & Analyst & Junior & $40-44$ & White & Partnered & \\
\hline$\# \mathrm{~L}$ & $\begin{array}{l}\text { Western } \\
\text { Europe }\end{array}$ & Australasia & Long-term & $\begin{array}{c}\text { Business } \\
\text { Development }\end{array}$ & Junior & $30-34$ & White & Partnered & \\
\hline$\# \mathrm{M}$ & $\begin{array}{l}\text { Western } \\
\text { Europe }\end{array}$ & Central Asia & Long-term & $\begin{array}{l}\text { Commercial } \\
\text { Manager }\end{array}$ & Middle & $40-44$ & White & Partnered & \\
\hline$\# \mathrm{~N}$ & $\begin{array}{l}\text { Western } \\
\text { Europe }\end{array}$ & Middle East & Long-term & Engineer & Junior & $35-39$ & Mixed & Partnered & \\
\hline$\# \mathrm{O}$ & $\begin{array}{l}\text { Western } \\
\text { Europe }\end{array}$ & Australasia & Long-term & IT Specialist & Junior & $40-44$ & White & Partnered & \\
\hline$\# \mathrm{P}$ & $\begin{array}{l}\text { Western } \\
\text { Europe }\end{array}$ & $\begin{array}{l}\text { Western } \\
\text { Europe }\end{array}$ & Long-term & Economist & Junior & $25-29$ & White & Partnered & 1 \\
\hline \#Q & Australasia & Central Asia & Rotation & Communications & Middle & $30-34$ & White & Partnered & \\
\hline$\# \mathrm{R}$ & $\begin{array}{l}\text { Western } \\
\text { Europe }\end{array}$ & Australasia & Long-term & $\begin{array}{c}\text { Performance } \\
\text { Manager }\end{array}$ & Middle & $30-34$ & White & Partnered & \\
\hline$\# \mathrm{~S}$ & Western & North Africa & Long-term & Commercial & Senior & $35-39$ & White & Partnered & 1 \\
\hline
\end{tabular}




\begin{tabular}{|c|c|c|c|c|c|c|c|c|c|}
\hline \#T & $\begin{array}{l}\text { Europe } \\
\text { Western } \\
\text { Europe }\end{array}$ & East Asia & Short-term & $\begin{array}{l}\text { Manager } \\
\text { Engineer }\end{array}$ & Graduate & $\begin{array}{l}24 \text { or } \\
\text { under }\end{array}$ & White & Single & \\
\hline \#U & $\begin{array}{l}\text { Western } \\
\text { Europe }\end{array}$ & North Africa & Long-term & Lawyer & Middle & $40-44$ & White & Partnered & 1 \\
\hline$\# \mathrm{~V}$ & Caribbean & $\begin{array}{c}\text { North } \\
\text { America }\end{array}$ & Long-term & Lawyer & Middle & $40-44$ & $\begin{array}{l}\text { Black - } \\
\text { African }\end{array}$ & Partnered & 1 \\
\hline$\# \mathrm{~W}$ & $\begin{array}{l}\text { Western } \\
\text { Europe }\end{array}$ & East Asia & Long-term & Geologist & Middle & $35-39$ & White & Partnered & 2 \\
\hline$\# \mathrm{X}$ & Caribbean & West Africa & Long-term & $\begin{array}{l}\text { Commercial } \\
\text { Manager }\end{array}$ & Middle & $40-44$ & Mixed & Single & \\
\hline \#Y & $\begin{array}{l}\text { Western } \\
\text { Europe }\end{array}$ & Central Asia & Long-term & $\begin{array}{c}\text { Commercial } \\
\text { Manager }\end{array}$ & Middle & $40-44$ & White & Partnered & \\
\hline \#Z & $\begin{array}{l}\text { Western } \\
\text { Europe }\end{array}$ & Central Asia & Rotation & Human Resources & Middle & $40-44$ & White & Partnered & \\
\hline
\end{tabular}

\footnotetext{
UK census 2011 ethnicity categories
} 
Table 4: Explanations of a priori themes/categories and emerging concepts

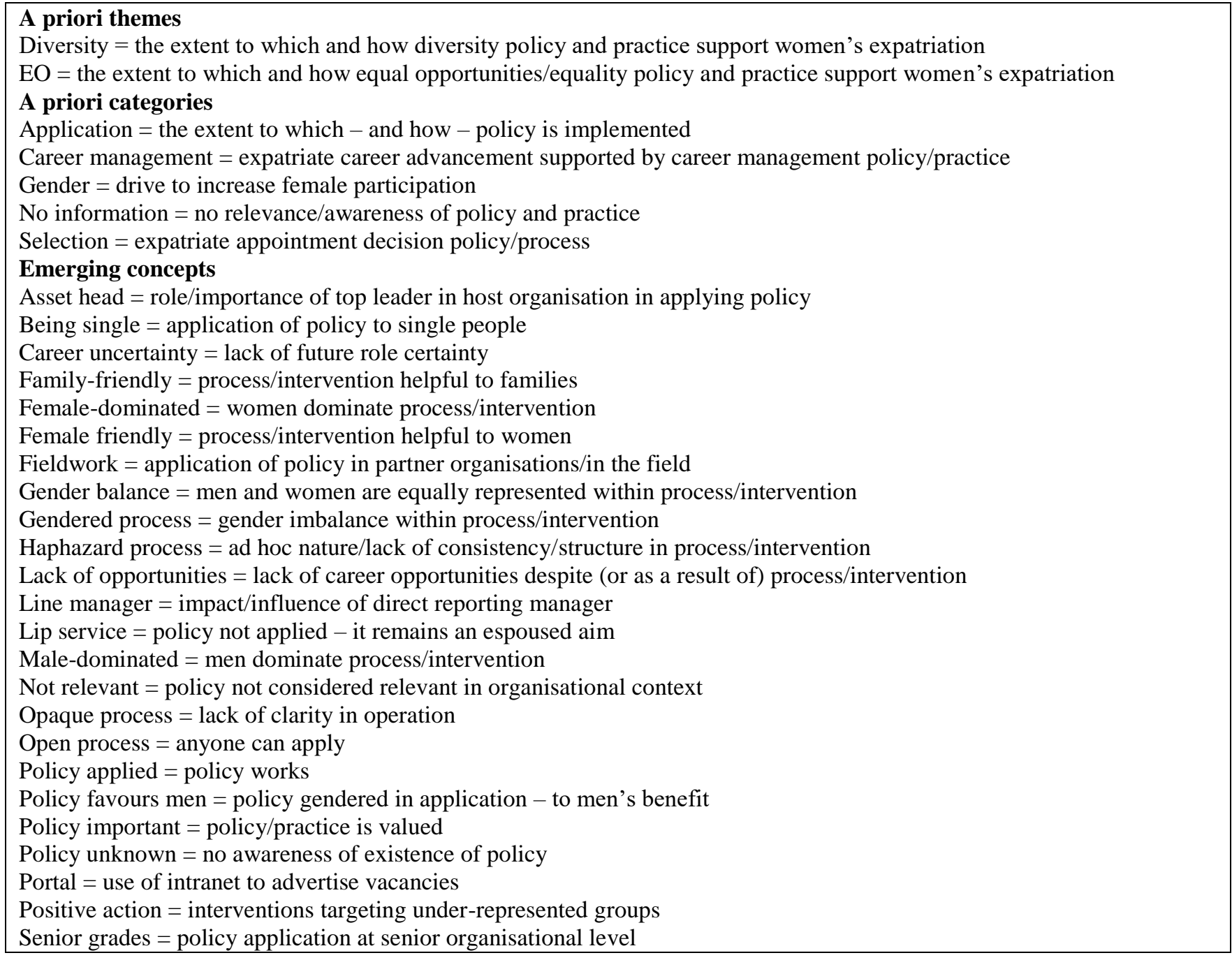




\section{Table 5: HR specialists' interview quotes}

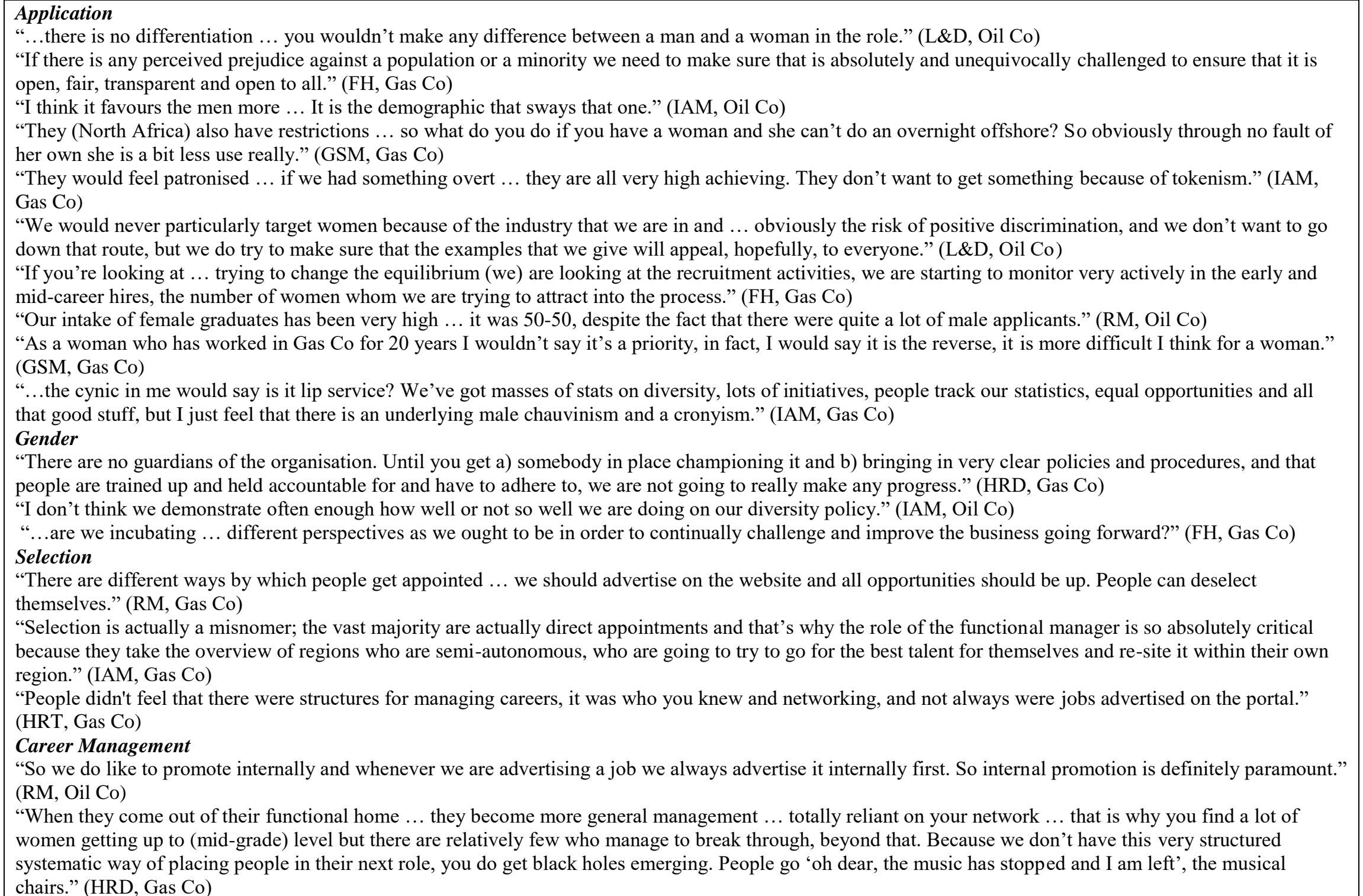


Table 6: Female expatriates' selected interview quotes displayed by grade

\begin{tabular}{|c|c|c|c|}
\hline Non-management/graduate scheme & Junior management & Middle management & Senior management \\
\hline $\begin{array}{l}\text { Gender } \\
\text { "I have not seen many women } \\
\text { working on management level (and) } \\
\text { in my function ... there are only two } \\
\text { of us in the whole group of men." } \\
\text { (\#G) } \\
\text { "I don't feel disadvantaged at all } \\
\text { right now, but I guess there will come } \\
\text { a point where I decide to start a } \\
\text { family and that would be a blocker } \\
\text { maybe." (\#J) } \\
\text { "I kind of thought, well actually this } \\
\text { wouldn't be a bad company to work } \\
\text { with, and I think my competitive } \\
\text { instinct was definitely heightened } \\
\text { when I was competing with the } \\
\text { males. The assessment centre was six } \\
\text { males and me. So I guess it wasn't } \\
\text { representative of an equal split." (\#T) } \\
\text { Selection } \\
\text { "I would want to see a project happen } \\
\text { ‥ go to my current supervisor and } \\
\text { tell him this is something that I think } \\
\text { would ... help my development." } \\
\text { (\#G) } \\
\text { "They guarantee graduates at least } \\
\text { one overseas assignment. The first } \\
\text { point of call (is my) manager to } \\
\text { discuss whether there is anything } \\
\text { available." (\#J) } \\
\text { "I pushed to move. I spoke to my } \\
\text { manager and the contracts manager." } \\
\text { (\#T) }\end{array}$ & $\begin{array}{l}\text { Application } \\
\text { "I don't think (the company) } \\
\text { discriminates against men or women; } \\
\text { there are women expats and there are } \\
\text { men expats." (\#F) } \\
\text { "One member of the team thinks } \\
\text { nothing of saying that he would } \\
\text { never work for a woman openly in } \\
\text { front of people. The culture is just } \\
\text { incredibly dismissive of working } \\
\text { women." (\#L) } \\
\text { "I don't think (Gas Co) has actively } \\
\text { behaved in any unequal way." (\#O) } \\
\text { Selection } \\
\text { "There was a posting and I applied } \\
\text { for it and I got it. That was easy." } \\
\text { (\#H) } \\
\text { Career management } \\
\text { "It is through informal channels you } \\
\text { let it be known that you will be } \\
\text { looking ... then you ring and say, I'm } \\
\text { looking to move, what are you going } \\
\text { to offer?"(\#I) } \\
\text { "They are not very good with } \\
\text { managing the next step so it seems } \\
\text {.. basically you are in limbo ... } \\
\text { I don't believe any policy with } \\
\text { respect to equal opportunity for } \\
\text { women. If they do it is lip service } \\
\text { only. Look at our management } \\
\text { composition for proof in key } \\
\text { roles...not many women beyond } \\
\text { lower middle management." (\#K) }\end{array}$ & $\begin{array}{l}\text { Application } \\
\text { "Whether, it is male or female, } \\
\text { getting the opportunity I didn't see a } \\
\text { difference and I hope it stays that } \\
\text { way." (\#X) } \\
\text { Selection } \\
\text { "It was advertised and I applied for } \\
\text { it, and ... I was on maternity leave. I } \\
\text { have to admit there was obvious } \\
\text { flexibility there, because I think the } \\
\text { desire was to have someone start } \\
\text { sooner." (\#A) } \\
\text { "My line manager ... a guy ... } \\
\text { made the classic mistake of } \\
\text { articulating the assumption that 'of } \\
\text { course I wouldn't be interested ... } \\
\text { because my partner was based here' } \\
\text { and I reacted by saying, 'why do } \\
\text { you think that? Of course I would } \\
\text { be interested'." (\#Z) } \\
\text { Career management } \\
\text { "They have got to see the benefit of } \\
\text { why you need a diverse organisation } \\
\text { and the benefits when you have got } \\
\text { that ... it needs to start from the } \\
\text { top."(\#E) } \\
\text { "It wasn't about what work you do } \\
\text { or how many barrels you've found, } \\
\text { it was did your boss like you? And } \\
\text { that kind of was the way it was and } \\
\text { still is. How well does your boss } \\
\text { know you?" (\#F) } \\
\text { "The percentage of women who are } \\
\text { in the sorts of roles that go } \\
\text { international, and the percentage } \\
\text { that have done ... you have to cut it } \\
\text { off at (mid-management)." (\#M) }\end{array}$ & $\begin{array}{l}\text { Application } \\
\text { "I know companies will tell you } \\
\text { everybody has got equal opportunity and } \\
\text { you nod your head and you go 'yes', but } \\
\text { you know that is not true ... And so I } \\
\text { think the bigger question is, you have } \\
\text { got females coming in, so what do you } \\
\text { need to do to make sure they have equal } \\
\text { opportunity?" (\#B) } \\
\text { "I was always told 'you don't look like } \\
\text { an engineer'. I am very petite, with long } \\
\text { blonde hair, and so I was always seen } \\
\text { more as a 'lady' versus an 'engineer' } \\
\text { and it is very tough to get over ... I hate } \\
\text { being put into a female bucket." (\#B) } \\
\text { Having been 'born' at (Gas Co) ... } \\
\text { trying to explain ... you are (senior) } \\
\text { looking for the next step up when they } \\
\text { still have this perception 'I can't believe } \\
\text { how much you have developed and how } \\
\text { far you have come', there's a subtext. He } \\
\text { remembers me as a graduate." (\#S) } \\
\text { Gender } \\
\text { "The vast majority of the jobs come } \\
\text { from the more traditionally male- } \\
\text { dominated functions, such as } \\
\text { engineering, geology, geophysics. So the } \\
\text { question is how could we try?" (\#S) } \\
\text { Career management } \\
\text { "There are very different perceptions on } \\
\text { what females need to do as opposed to } \\
\text { what males need to do to get to the next } \\
\text { level. From grade (senior) and up, you } \\
\text {... see a bunch of people who all look } \\
\text { the same ... white males! I don't see any } \\
\text { advancement past where I am now. } \\
\text { External, I'd definitely look." (\#B) }\end{array}$ \\
\hline
\end{tabular}



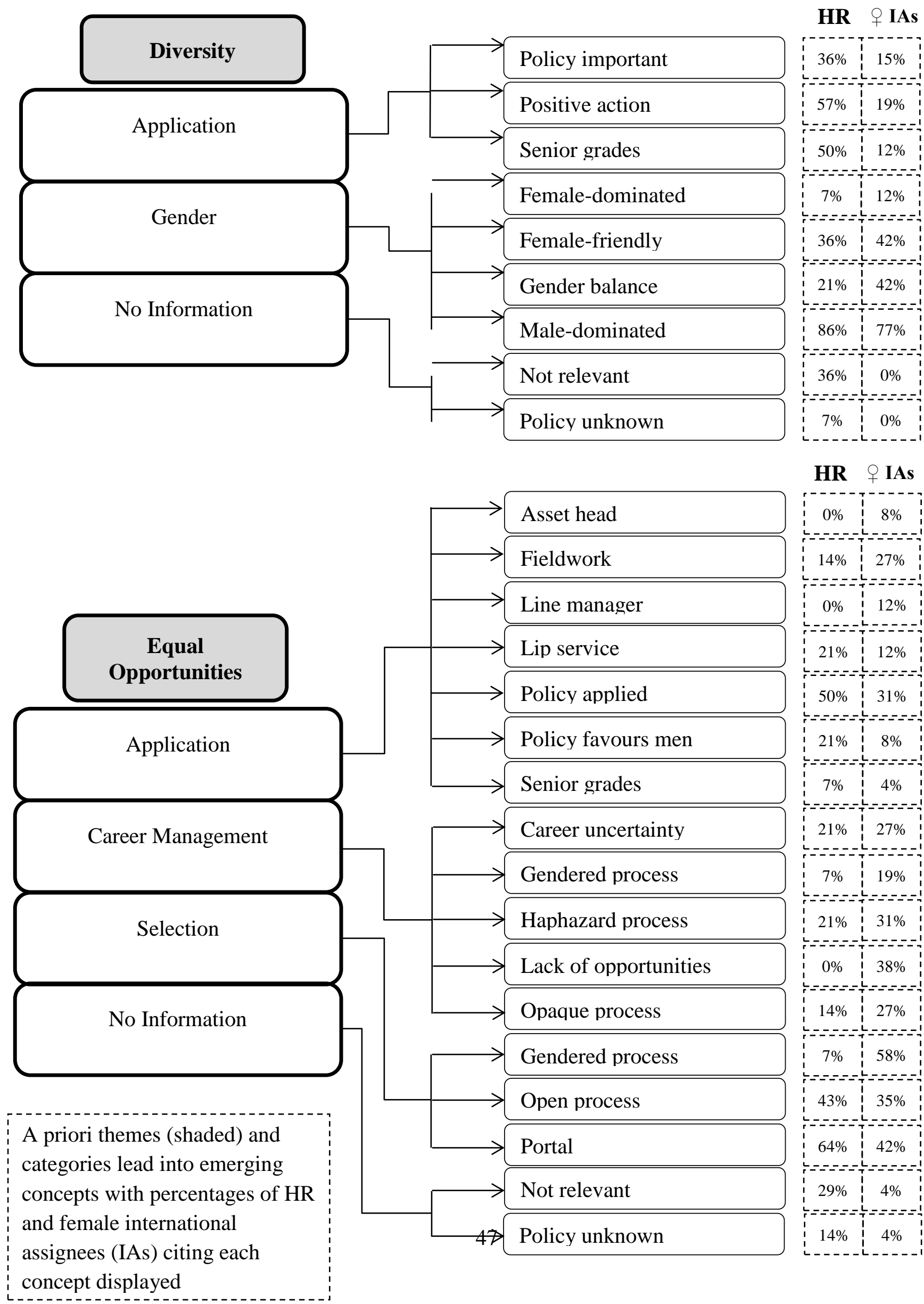

HR $\odot$ IAs

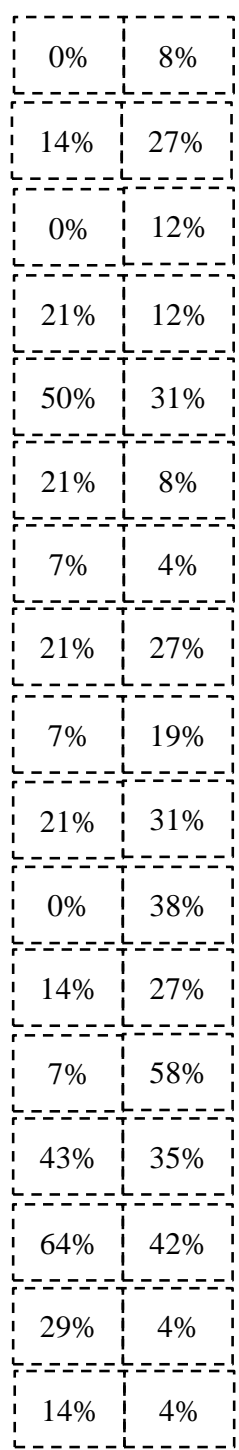

